\title{
An Empirical Analysis of the Career Expectations of Women in Science and Technology Courses
}

\section{Alison Preston}

\section{ABSTRACT}

Using data from a recent survey of first year university students, this study examines the career and occupational expectations of students enrolled in science and technology courses as a way of shedding further light on the labour market outcomes of women in these fields. It has been suggested that women's apparent lack of career success in science and technology stems from factors such as their lack of motivation and career commitment. Findings in this study show shared career goals and expectations between the young male and female science and technology students, but differences in expected family care plans. Young women typically see themselves balancing work and family responsibilities through engagement in part-time work, while young men typically envisage that they will work full-time and take on the main breadwinner role. The findings highlight the likelihood of an ongoing masculine culture within science and technology and call for efforts to ensure quality part-time work if the industry is to avert ongoing skill shortages and retain highly qualified women who hold similar career aspirations to men.

\section{Introduction}

Much of the empirical research on occupational choice has focused on outcomes and the factors determining occupational success, satisfaction and earnings. Despite the strong emphasis given to occupational expectations and career plans in theoretical literature, comparatively less empirical attention has been paid to these issues (see Weinberger 2004: 28-9). It might be argued that the existing focus on outcomes relates to the dominance of human capital theory as an explanation of labour market behaviour. In this framework, individuals are assumed to weigh 
the advantages and disadvantages (trade-offs) of different labour market outcomes when they make a range of participation decisions. ${ }^{1}$ Although the theory has strong theoretical appeal in some quarters, there is growing concern that the neglect of important institutional and contextual features of the labour market is contributing to constrained (and sometimes misguided) policy development.

In this paper, data from a recent survey of first year university students are used to study the career plans and occupational expectations of young people, with particular attention given to students enrolled in Science and Technology (S\&T) courses (which include Information technology [IT] programs). The focus on S\&T stems from two drivers: the ongoing debates around women's apparent lack of success in this field, particularly in IT; and the forecast shortage of skilled S\&T professionals. Focusing specifically on gender differences, this paper also seeks to identify those findings which appear consistent with human capital theory and those which might more adequately be defined by a different theoretical approach. The overall aim is to broaden debate and contribute to the development of more appropriate policies to assist with the attraction and retention of skilled S\&T professionals.

The remainder of the paper is organised as follows. The next section outlines the theoretical role of occupational expectations in occupational choice. This is followed by a section presenting the empirical analysis, which compares female S\&T students with other female students and with male $S \& T$ students, and analyses influences on the likelihood of enrolling in S\&T. The final section provides a summary and discussion.

\section{Theories of Occupational Choice}

Much has been written on the theory of occupational and career choice with strands of debate reflecting on the meaning or concept of career (for example, Poole and Langan-Fox 1997). Broadly, theories on occupational choice may be classified as economic, psychological and sociological, although the disciplinary boundaries are blurring as feminist theory and cross-disciplinary approaches explicitly acknowledge interrelationships across disciplinary areas.

Despite recent cross-disciplinary approaches, however, Gary Becker's (1975) use of human capital theory continues to carry significant weight as an explanation of career and occupational choice both within economic literature and policy making circles. Human capital theory uses principles such as rationality and utility maximisation to explain individual decision making with respect to human capital investments and choice of career. Within this neo-classical model it is assumed that young women's educational, occupational and career choices are mediated by expectations of marriage, childbearing and other domestic responsibilities. 
According to Becker (1975: 74), '... a woman wants her investment to be useful both in her roles as a housewife and as a participant in the labour market'. A key hypothesis, therefore, is that women choose to invest their efforts in securing occupations where their returns (lifetime earnings) are lower but where the penalties attached to intermittent labour force attachment are also less (see also Polachek 1981). Women are similarly assumed to select jobs or occupations where their level of responsibility is lower, thus making it easier to balance work and family responsibilities. Although conceptually simplistic, the model has received wide support as an explanation of the causes of observed patterns of occupational segregation and gender wage inequalities. Human capital theory, explained in Becker's terms, renders theories of discrimination and unequal labour market treatment unnecessary when explaining the poor pay outcomes of highly feminised occupations.

Human capital theory was first conceived more than four decades ago at a time when fewer than twenty percent of married women were participating in the Australian labour market. Today the share is over 65 percent (see Preston and Burgess 2003). This has coincided with a contemporary emphasis on individual choice within theoretical and political approaches to labour market policy and a resurgence of human capital as an explanation of gendered labour market outcomes. At the same time, there appears to be a relative neglect of the feminist analyses that provide alternative explanations of women's experiences in paid and unpaid work (for a specific focus on women in science and technology, see Wajcman 1991; Webster 1996; Wyer et al 2001; on occupational sex segregation more generally, see for example Reskin and Roos 1990).

At a time when young women constitute the majority of university undergraduate students and when skill shortages are increasingly being experienced in critical areas of the economy (engineering, science and technology, nursing, teaching, law) the dominance and resilience of human capital theory as the sole or key explanation of women's occupational outcomes is remarkable. Its focus on individual choice and treatment of institutional aspects of decision making as exogenous has left practitioners and policy makers poorly equipped to acknowledge and address contextual factors that inform the career plans, expectations and labour market outcomes of women. As a result, Australia can expect to face ongoing skill shortages and productivity losses across the economy, not to mention a decline in fertility (McDonald 2000).

From both a policy and theoretical perspective we need to understand the full range of factors influencing occupational expectations, career choice, and labour market outcomes. This includes the roles played by social conditioning, society norms, family influence, and the nature of different types of work. The following analysis considers the strengths and weaknesses of human capital theory as an 
explanation of career decisions among first year university students. It identifies some key aspects of career decision making which may remain neglected if human capital theory continues as the key theoretical approach to examining this important area of labour market policy.

\section{Empirical Analysis}

The empirical component of this paper is based on an analysis of data from a survey undertaken in 2003 that focused specifically on career plans and expectations among first year university students. ${ }^{2}$ Entitled the First Year Student Survey (FYSS), it was based on a random sample of $\mathbf{4 5 0 0}$ first year students enrolled across five universities in Perth, Western Australia. The survey generated a response rate of approximately 34 percent, with responses received from 1012 female and 491 male students. 3

After rejecting those enrolled in bridging courses, the sample was reduced to 1441 , with the 51 women enrolled in S\&T courses (which included Chemistry, Physics, Engineering, Information Technology, and Information Systems) accounting for 5.3 percent of the 962 remaining women in the sample. ${ }^{4}$ Men enrolled in S\&T courses accounted for 36 percent of the 479 men in the sample.

\section{High school years}

Within the literature on occupational choice reference is frequently made to the importance of school experience in shaping career expectations and career choice decisions (see, for example, Whitley 1997). This literature suggests that performance and interest in particular subjects can give rise to particular choices, as can the influence of teachers, parents and career guidance officers. The literature also highlights correlations among technical expertise (such as computer interest), gender beliefs, and school environment, with single-sex schools seen as providing a more supportive base for participation in non-traditional occupations.

Looking at the background characteristics of survey respondents it would appear that, across a range of characteristics, female S\&T students differ from other female students and male S\&T students (see Table 1). When compared with other female students, female S\&T students were, for example, significantly more likely to have attended a government or co-educational school, they reported a higher self-assessed performance in physical sciences and mathematics, and had been actively encouraged to enrol into their current course of study by their father (or primary male guardian).

These appear to be important factors in course choice (taken here as a proxy for career choice) that are neglected by human capital theory. That is, it appears 
that factors unrelated to earnings expectations are important in informing the occupational preferences of young women. In particular, it appears that there are relationships between educational context and mentoring from a male guardian that have an effect on career choice.

\section{Table 1: Pre-university background characteristics (mean scores)}

\begin{tabular}{|c|c|c|c|}
\hline & $\begin{array}{r}\text { Female } \\
\text { Science \& } \\
\text { Technology } \\
\text { Students }(a)\end{array}$ & $\begin{array}{r}\text { Other } \\
\text { Female } \\
\text { Students(b) }\end{array}$ & $\begin{array}{l}\text { Male Science } \\
\text { \& Technology } \\
\text { Students(c) }\end{array}$ \\
\hline Type of high school attended (1=govt, 2=private) & 1.42 & $\star \star 1.49$ & 1.45 \\
\hline Single-sex school ( $1=$ single, $2=$ co-ed) & 1.82 & $* * 1.78$ & 1.86 \\
\hline \multicolumn{4}{|l|}{$\begin{array}{l}\text { Self-assessed subject performance at high school } \\
\text { (Scale 1-5: } 1=\text { high; } 5=10 w \text { ) }\end{array}$} \\
\hline Performance in physical sciences & 2.42 & $" 2.70$ & $* 1.93$ \\
\hline Performance in biological sciences & 2.05 & *1.99 & "*2.32 \\
\hline Performance in mathematics & 2.10 & $* 2.37$ & $* * 1.76$ \\
\hline Performance in English & 2.24 & $* 2.16$ & $* 2.73$ \\
\hline Performance in social sciences & 2.24 & $* 2.14$ & $* 2.09$ \\
\hline Tertiary Entrance Exam (TEE) mark & 86.24 & 86.69 & $* 88.91$ \\
\hline \multicolumn{4}{|l|}{$\begin{array}{l}\text { Parental encouragement to enrol in course } \\
\text { ( } 1=\text { parent actively encouraged; } 2=\text { parent was } \\
\text { happy with choice of course; } 3=\text { parent had other } \\
\text { plans; } 4=\text { other) }\end{array}$} \\
\hline Mother (or primary female guardian) & 1.80 & $* * 1.72$ & 1.84 \\
\hline Father (or primary male guardian) & 1.77 & $* 1.86$ & 1.73 \\
\hline
\end{tabular}

(a) Number of observations ranges from 42 to 50 (biological sciences excepted); (b) observations range from 607 to 903; (c) observations range from 147 to 153 (biological sciences excepted). ** indicates a significant difference in the mean and the recorded mean from the sample of female S\&T students (significant at the five percent level using a two-sided z-test statistic). Source of data: First Year Student Survey, Perth, 2003.

\section{Course and occupation expectations}

In addition to collecting background information on high school years the survey also asked respondents to rate the importance of a range of factors thought to have influenced their choice of course. Respondents were similarly asked to reflect on the importance of specific job characteristics in their preferred occupation. 5 As before, the mean responses of female S\&T students are compared with two other groups (other females and male S\&T students). Results are presented in Table 2.

The upper panel in Table 2 shows that the factors that most influenced female S\&T students in selecting their course of study were good career opportunities, 
employability and future earning potential. While these items were also rated highly by the other groups, several significant differences between female S\&T students and females in other courses were evident. For example, relative to females in other courses, S\&T female students appear to have placed more weight on aspects such as good career opportunities, future earnings potential, career/teacher advice, and course prestige when choosing their course of study. The availability of scholarships and other financial support as well as school-based work experience programs also appear to have been a stronger influence for these students, suggesting that such policies may be helping to redress the gender imbalance in such 'non-traditional' courses.

Table 2: Importance of factors influencing choice of course and in preferred occupation (mean scores)

\begin{tabular}{|c|c|c|c|}
\hline & $\begin{array}{r}\text { Female } \\
\text { S\&T } \\
\text { Students }\end{array}$ & $\begin{array}{r}\text { Other } \\
\text { Female } \\
\text { Students }\end{array}$ & $\begin{array}{r}\text { Male S\&T } \\
\text { Students }\end{array}$ \\
\hline \multicolumn{4}{|l|}{$\begin{array}{l}\text { Importance given to factors when selecting course of } \\
\text { study }(1=\text { low; } 5=\text { high })\end{array}$} \\
\hline Good career opportunities & 4.27 & $* 4.14$ & 4.38 \\
\hline Qualification will make me highly employable & 3.82 & $* 3.92$ & $* 4.21$ \\
\hline Future earning potential & 3.75 & $* 3.28$ & $\star 4.03$ \\
\hline Ability to do the course / meet course demands & 3.73 & 3.79 & 3.85 \\
\hline Practical experience is significant component of course & 2.84 & $* 2.98$ & 2.74 \\
\hline $\begin{array}{l}\text { Course is quite general, should give range of job } \\
\text { possibilities }\end{array}$ & 2.82 & $* 3.15$ & $* 3.01$ \\
\hline Course considered prestigious & 2.53 & $* 2.43$ & **2.94 \\
\hline Career adviser / teacher advice & 2.30 & $* * 2.18$ & 2.21 \\
\hline Time it will take to qualify for chosen career & 2.27 & "*2.18 & 2.19 \\
\hline Able to earn money as part of studies & 2.26 & $* * 1.82$ & $* 1.95$ \\
\hline Cost of the course (HECS / other) & 2.00 & 1.93 & $* 1.71$ \\
\hline Availability of scholarships \& other financial support & 1.86 & $\star * 1.68$ & $\star * 1.59$ \\
\hline School-based work experience program & 1.84 & $" * 1.67$ & $* 1.50$ \\
\hline Other work experience & 1.69 & $* * 1.81$ & $* " 1.49$ \\
\hline Previous paid work experience & 1.52 & 1.47 & 1.40 \\
\hline Accommodation provided while studying & 1.30 & 1.29 & 1.36 \\
\hline \multicolumn{4}{|l|}{$\begin{array}{l}\text { Importance of factors in preferred occupation }(1=10 w \text {; } \\
5=\text { high })\end{array}$} \\
\hline Interesting work & 4.57 & *4.64 & $* 4.45$ \\
\hline Good career opportunities & 4.38 & 4.37 & 4.31 \\
\hline
\end{tabular}




\begin{tabular}{llrr} 
Exciting work & 4.06 & $* 4.16$ & $* 3.93$ \\
Future earning potential & 3.98 & $* 3.67$ & $* 4.25$ \\
Opportunities for travel & 3.86 & $* 3.79$ & $* 3.49$ \\
Pleasant working conditions & 3.78 & $* 3.95$ & 3.67 \\
Job security & 3.75 & $* 3.82$ & 3.68 \\
Opportunity for promotion/advancement & 3.67 & $* 3.49$ & 3.74 \\
Combine work and family commitments & 3.65 & 3.70 & $* 3.07$ \\
Challenging work & 3.65 & $* 3.78$ & $* 3.48$ \\
Opportunity for creativity and originality & 3.57 & $* 3.49$ & 3.50 \\
Responsibility in job & 3.53 & $* 3.73$ & 3.47 \\
Working to help others & 3.47 & $* 3.94$ & $* * 2.80$ \\
Make strong contribution lo society & 3.37 & $* 3.75$ & $* * 3.05$ \\
Working closely with people & 3.27 & $* 3.82$ & $* 2.74$ \\
Flexible working hours & 3.27 & $* 3.36$ & $* 2.81$ \\
Graduate starting salary & 3.24 & $* 3.06$ & $* 3.60$ \\
Community respect for occupation & 3.12 & $* 3.40$ & $* 2.90$ \\
Ability to leave workforce and return later & 2.98 & $* 3.57$ & $* 2.78$ \\
Professional prestige / high status & 2.90 & 2.87 & $* 3.10$ \\
\hline
\end{tabular}

See notes to Table 1 above. The mean responses for female S\&T students are presented in rank order.

Source of data: First Year Student Survey, Perth, 2003.

Turning to desired job characteristics of specific occupations (lower panel, Table 2), the top four characteristics as rated by the female S\&T students were interesting work, good career opportunities, exciting work, and future earning potential. Again there were significant differences between the groups under study. Relative to females in other courses, female S\&T students rated the importance of graduate starting salary, future earning potential, opportunities for promotion/ advancement, opportunities for travel, and opportunities for creativity and originality significantly higher. They (female S\&T students) placed significantly less emphasis on flexibility, ability to take periods out of the workforce, community respect for the occupation, working to help others, working closely with others, and responsibility in the job. Perhaps importantly there was no significant difference between female S\&T students and females in other courses in the importance they attached to the ability to combine work and family commitments.

While female S\&T students thus appear to place less emphasis on the potential flexibility of their labour market arrangements, it is unclear from this survey whether this reflects a working knowledge of the types of labour market arrangements they might wish to access in later life. The retention rate of women 
in some sectors of the S\&T (for example, IT and engineering) is notoriously low (see Bentley 2003; Roberts and Ayre 2002). This suggests that, for some women at least, earlier expectations of workforce participation have not been met. For other women, however, it may be the case that a relative lack of flexibility has been taken into account and is not of concern. Without understanding the level of knowledge or information among decision-makers, it is difficult to assess whether human capital theory provides a comprehensive explanation of the relative importance given to these drivers of career choice.

The occupational expectations of female S\&T students and male S\&T students also varied significantly. For example, although there was no significant difference across the two female groups in importance attached to work and family commitments, relative to male S\&T students, the female S\&T students attached significantly more weight to this job characteristic. When compared with their male S\&T counterparts, female S\&T students also attached significantly more weight to the people factors (such as helping others, working with people, contributing to society) and significantly less weight to starting salary and earnings potential. Both groups (male and female S\&T students) rated career opportunities, job security, opportunities for promotion and job responsibility as equally important. This suggests that while earnings and employment outcomes provide important motivations for choosing S\&T as a potential career, female S\&T students appear to have their expectations tempered by gender norms relating to women's caring roles within family units. Whether this can be adequately explained by human capital theory alone is debatable, as the importance of social norms in such 'individual' choices suggests that there are more complex interrelationships at work (see for example Cooper and Weaver 2003).

To elaborate the issue of future earnings potential, Figure 1 illustrates the subjective earnings expectations of S\&T students over their life course. Over the first ten years the earning expectations of male and female S\&T students were relatively comparable, and it is only over the long term that a projected gap emerges. Of perhaps equal interest was the relatively high non-response rate to questions on earnings expectations (see note to Figure 1). This suggests that, contrary to the predictions of human capital theory, many respondents held uncertain expectations with respect to earnings and earnings growth.

Work, family and gender roles

A small share of female and male S\&T students (eight and ten percent, respectively) reported that they did not plan on having children. Of the remainder, the expected 
mean family size held by female and male S\&T students was 2.36 and 2.18 children respectively. Figure 2 shows that of the S\&T women who do plan to have children, around 64 percent envisaged taking a significant career break of between one and five years. Fewer than fifteen percent saw themselves returning to work before their youngest child was one year old (a slightly lower percentage than among other female students). In contrast, 90 percent of the male S\&T students imagined being back at work before their youngest child was one (the corresponding figure for other male students was less than 80 percent).

Figure 1: Expected starting salary and earnings growth (2003 Australian dollars)

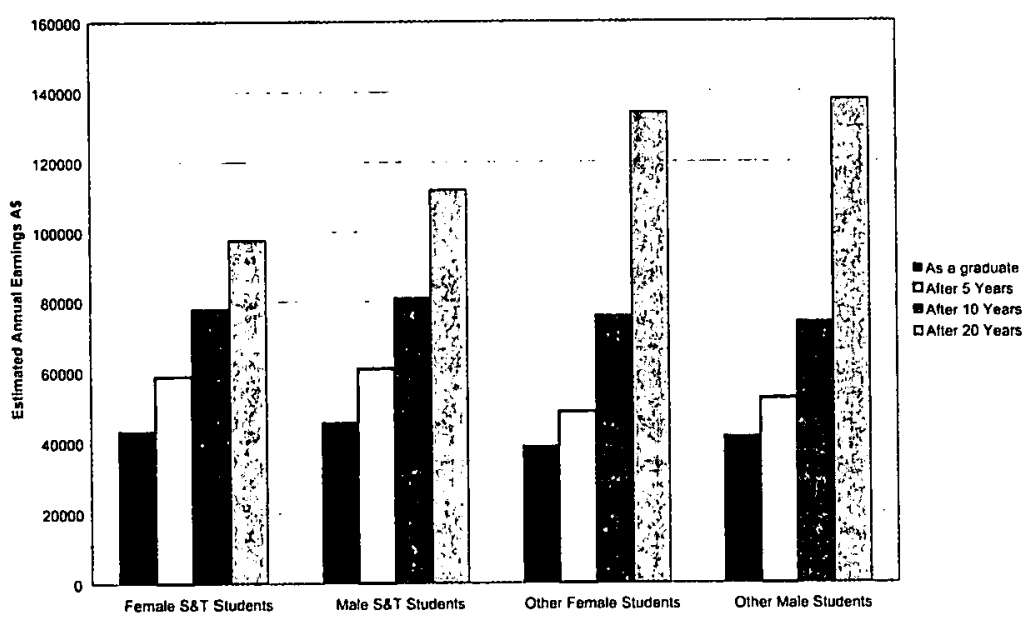

High levels of non-response to this question reduced sample sizes as follows: (a) female S\&T students, $n=9-13$ out of 51 ; (b) male $S \& T$ students, $n=71-98$ out of 175 ; (c) other female students, $n=182-265$ out of 911 ; (d) other male students, $n=80-123$ out of 304 .

Source of data: First Year Student Survey, Perth, 2003

Figure 3 shows the imagined employment arrangements of the $S \& T$ students as parents within a couple relationship. Just over one quarter ( 26 percent) of the S\&T female students imagined themselves in a couple partnership where both parents work full-time (this was, however, a higher percentage than among other female students). The most commonly imagined arrangement (by all groups) was one where the father works full-time and the mother works part-time. 
Figure 2: Anticipated age of youngest child when respondent returns to work

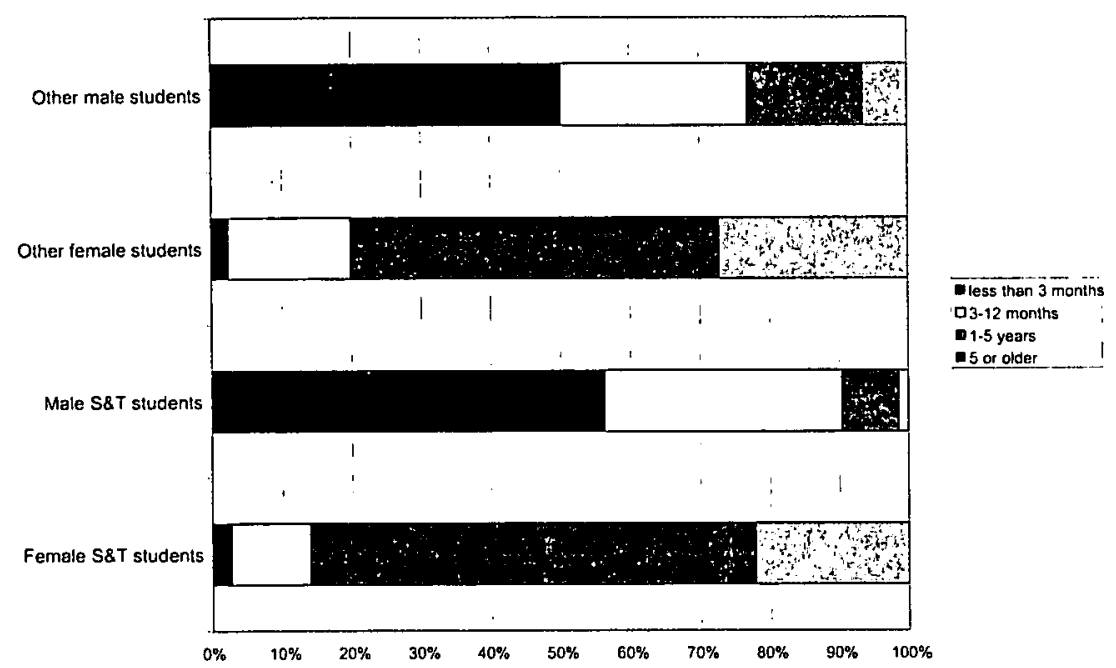

Notes: Sample sizes are as follows: (a) female S\&T students, 51 ; (b) male S\&T students, 175; (c) other female students, 911; (d) other male students, 304 .

Source of data: First Year Student Survey, Perth, 2003

Based on the data presented here it seems fair to conclude that the vast majority of young professional women in Australia, at least initially, expect to become the primary care giver should they have children. They similarly expect to have lengthy periods of time out of the workforce. Whether these women see themselves making this decision by 'choice' or because of prevailing ideologies and social norms surrounding motherhood is something that cannot be determined from these data.

At best, it appears that human capital theory provides a partial explanation. For example, there appear to be contradictions between the data and human capital theory's prediction that women self-select into occupations that will allow them to better balance their work and family responsibilities. Many of the female S\&T students expect to become mothers and primary care givers. However, it appears they have attached relatively little importance to job characteristics such as hours flexibility and job flexibility (for example, the ability to exit and enter the occupation and the ability to combine work and family). Notwithstanding their likely different needs the female and male S\&T students have shared occupational expectations with respect to factors such as the nature of the work, earnings and career opportunities. The significant differences in the female and male S\&T student expectations surrounding work and family as well as in the importance given to 
these factors as desired job characteristics may well provide some insight into observed problems experienced by female $S \& T$ practitioners in industry - in particular a mismatch between expectations and later experiences. ${ }^{6}$ This appears to be exactly the type of issue that remains neglected when human capital theory is used as the sole approach to examining labour market issues.

\section{Figure 3: Imagined working arrangements as parents in a couple relationship}

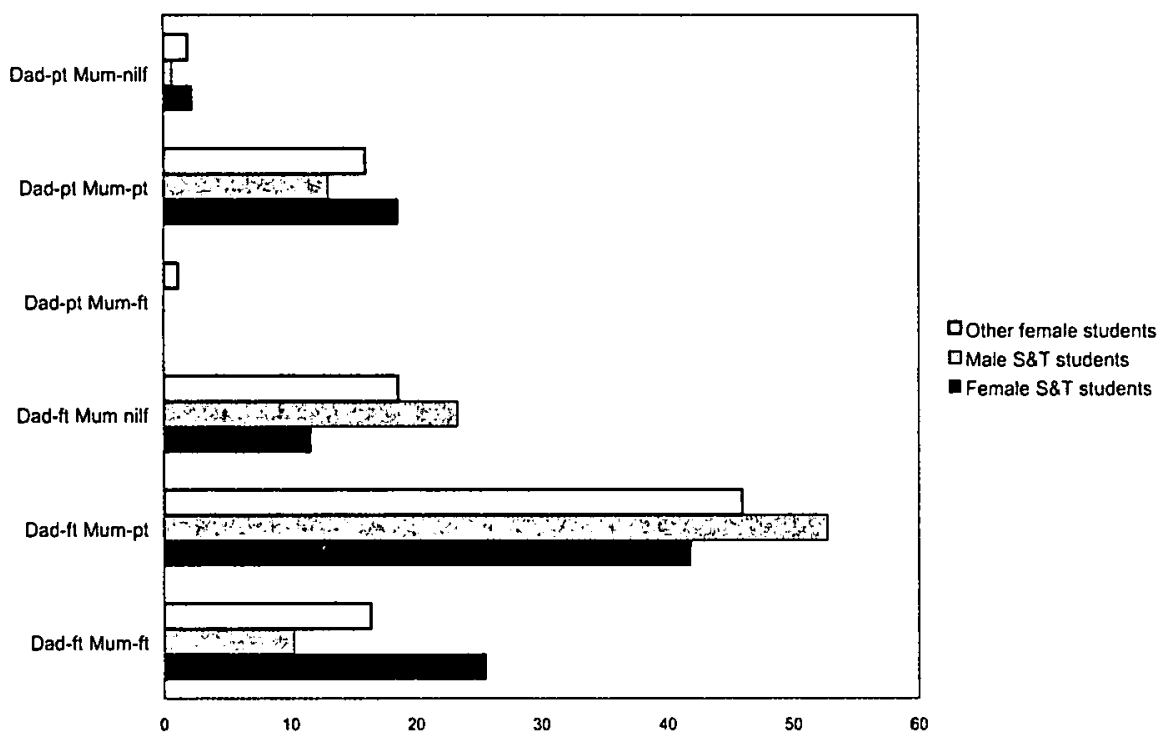

Sample sizes are as follows: (a) female S\&T students, 51; (b) male S\&T students, 175; (c) other female students, 911; (d) other male students, 304.

Source of data: First Year Student Survey, Perth, 2003

\section{Multivariate analysis of influences on career choice}

As might be expected there will be multiple correlations between the decision to pursue a career in S\&T and the various factors related to career expectations and plans. To assess the independent effect of individual variables on course of study (taken here as a proxy for career choice) a standard logistic regression model is used. The dependent variable is S\&T (a binary variable is set equal to one if the student is enrolled in a science and technology course). Table 3 presents three sets of regression results based on: (a) a sample of all students; (b) a sample of female students; and (c) a sample of S\&T students. 
The goal of this analysis is to test the strong predictions from human capital theory which suggest that occupational choice will be affected by fertility plans and anticipated family caring plans, with these variables likely to affect expectations with respect to factors such as earnings growth and job responsibility. The relationship between background characteristics (such as high school experience, ability, and parental education) and career choice is also explored.

In the model presented in Table 3, therefore, controls are included for schooling type (the variables 'private' and 'ssex' capture whether or not the individual attended a private rather than government high school and a single-sex rather than a co-educational school) as well as self-assessed ability in mathematics and English (a dummy variable for each subject is set equal to one if the respondent's selfassessed performance was above average or excellent). Three variables 'mumw', 'mumed' and 'daded' control for parental background, which is theorised as an important determinant of course and career choice amongst young people. 'Mumw' captures whether or not the primary female caregiver during high school worked in paid employment. 'Mumed' and 'daded' capture effects of parental educational background. If the primary female or male care giver during high school years had a tertiary qualification the variable concerned is set equal to one.

'TEE' measures student performance in the tertiary entrance exam, 'kids' measures the number of children the respondent would ideally like to have sometime in the future (fertility expectations), and 'mumpt' is set equal to one if respondents envisage themselves in a partnered relationship where parenting is managed through the combination of a father employed full-time and a mother employed part-time.

Finally, the model controls for a set of factors perceived as important or desirable in any future occupation. Each variable in this group is equal to one if the respondent indicated the feature was either important or very important. 'Career', for example, is equal to one if the respondent seeks an occupation with good career prospects. 'Futearn' is similarly equal to one if the respondent ranked future earnings potential as important or very important. 'Leave' measures the importance of flexibility (as measured by the ability to leave and easily return to the occupation), while 'work\&fam' captures the extent or importance of the ability to combine work and family responsibilities. 'Travel', 'respon', 'interest', 'nicecon', 'excite', 'chal' and 'people' capture, respectively, the importance of opportunities for travel, job responsibility, interesting work, pleasant working conditions, exciting work, stable employment, challenging work, and interaction with people. 
Table 3: Logistic regression results for the likelihood of being an S\&T student (or a female in an S\&T course)

\begin{tabular}{|c|c|c|c|c|c|c|c|c|c|}
\hline & \multicolumn{3}{|c|}{$\begin{array}{l}\text { All Students: } \\
\text { Prob of being } \\
\text { S\&T student }\end{array}$} & \multicolumn{3}{|c|}{$\begin{array}{l}\text { All female Students: } \\
\text { Prob of being } \\
\text { S\&T student }\end{array}$} & \multicolumn{3}{|c|}{$\begin{array}{l}\text { All S\&T students: } \\
\text { Prob of being } \\
\text { female }\end{array}$} \\
\hline & coef & se & sig & coef & se & sig & coef & se & sig \\
\hline constant & -2.353 & 1.151 & $* *$ & -26.724 & $2 E+05$ & & -20.492 & $2 E+05$ & \\
\hline female & -2.350 & 0.243 & $\cdots$ & - & - & & - & & \\
\hline tee & 0.014 & 0.013 & & -0.022 & 0.021 & & -0.063 & 0.037 & * \\
\hline kids & -0.167 & 0.098 & * & -0.212 & 0.199 & & 0.087 & 0.202 & \\
\hline mumpt & 0.131 & 0.223 & & -0.026 & 0.452 & & -0.193 & 0.566 & \\
\hline private & -0.167 & 0.248 & & -0.032 & 0.492 & & -0.154 & 0.648 & \\
\hline ssex & -0.330 & 0.311 & & -0.122 & 0.638 & & 0.457 & 0.799 & \\
\hline math & 0.920 & 0.281 & $* *$ & 0.818 & 0.490 & " & -0.771 & 0.749 & \\
\hline english & -0.619 & 0.219 & $m$ & -0.095 & 0.454 & & 1.536 & 0.599 & ** \\
\hline career & -0.093 & 0.385 & & -0.43 & 0.863 & & 0.264 & 1.120 & \\
\hline futearn & 0.921 & 0.308 & $* * *$ & 1.011 & 0.627 & * & -0.893 & 0.825 & \\
\hline leave & -0.417 & 0.239 & * & -0.322 & 0.454 & & 0.497 & 0.562 & \\
\hline work\&fam & 0.029 & 0.240 & & -0.049 & 0.473 & & 0.321 & 0.685 & \\
\hline Iravel & -0.059 & 0.232 & & 0.676 & 0.521 & & 0.459 & 0.658 & \\
\hline respon & 0.322 & 0.246 & & 1.129 & 0.549 & * & 0.389 & 0.719 & \\
\hline interest & 0.496 & 0.447 & & 25.623 & $2 \mathrm{E}+05$ & & 24.158 & $2 E+05$ & \\
\hline nicecon & 0.130 & 0.261 & & 0.436 & 0.580 & & 0.555 & 0.767 & \\
\hline excite & 0.038 & 0.284 & & -0.131 & 0.526 & * & -1.389 & 0.685 & ** \\
\hline security & -0.045 & 0.246 & & 0.016 & 0.496 & & 0.223 & 0.703 & \\
\hline people & -1.062 & 0.245 & $* *$ & -0.415 & 0.466 & & 0.892 & 0.635 & \\
\hline chal & 0.388 & 0.240 & & 0.096 & 0.483 & & 0.0145 & 0.638 & \\
\hline mumw & -0.476 & 0.241 & ** & -0.544 & 0.449 & & -0.062 & 0.572 & \\
\hline mumed & -0.127 & 0.230 & & -0.014 & 0.458 & & 0.274 & 0.584 & \\
\hline daded & 0.397 & 0.237 & * & -0.355 & 0.453 & & -0.799 & 0.607 & \\
\hline$N$ & 914 & & & 578 & & & 167 & & \\
\hline $\begin{array}{l}\text { Observations = } \\
1 \text { (dependent } \\
\text { var) }\end{array}$ & 167 & & & 27 & & & 27 & & \\
\hline $\begin{array}{l}\text { Number } \\
\text { predicled }\end{array}$ & 80 & & & 0 & & & 9 & & \\
\hline Pseudo R2 & 0.316 & & & 0.117 & & & 0.26 & & \\
\hline
\end{tabular}

$*, * *, * *$, significant at the 10,5 and 1 percent levels respectively

Source of data: First Year Student Survey, Perth, 2003 
From the results it can be seen that, even after controlling for sex, there were some important differences in the cohort of S\&T students and other first year university students with respect to occupational expectations and background characteristics. S\&T students, for example, were much more likely to see themselves as having been good at mathematics at high school and poorer at English. They were also much more likely to rate future earnings as an important feature of their desired occupation, but less likely to rate flexibility to leave and return to the occupation highly, or to rate interaction with people as important in their work. Parental background also appeared to exert an influence: if the primary female care giver worked in paid employment when the student was in high school, the student was less likely to be enrolled in an S\&T course, but if the primary male care giver had a tertiary qualification the student was more likely to be enrolled in an S\&T course.

In the second set of results the focus is on female first year university students alone. Of the sample of 578 women (with valid data on all variables in the model), 27 were enrolled in S\&T courses. The two groups (female S\&T students and other students) appear to be fairly similar with only a handful of variables statistically significant (self-assessed mathematics ability, future eainings, job responsibility and exciting work). The overall explanatory power of the model is relatively low and the model fails to correctly predict any S\&T students on the basis of the characteristics controlled for.

The final set of results is based on a sample restricted to S\&T students, with the focus on understanding the differences, if any, in the characteristics of male and female S\&T students. In other words it asks the question: 'given these characteristics and occupational expectations what is the probability that the S\&T student is female?' Whilst the predictive power of the model is slightly higher (equal to 26 percent), it appears that male and female S\&T students only differ on a few points: TEE score; self-assessed English ability; and the importance attached to exciting work. Across all other variables (including school background, parental background, and occupational expectations) there is no significant difference in the characteristics of male and female S\&T students.

From a human capital perspective these results lend, at best, partial support to the argument that women who plan on having children and taking time out of the labour market are likely to self-select into less responsible jobs where earnings growth is flatter and where the penalty for career entry and exit are lower.

Amongst female S\&T students the important or significant career drivers appear to be future earnings and job responsibility whilst family factors such as children and work and family are insignificant predictors. This is somewhat surprising given that more than 90 percent of female S\&T students anticjpate having children and more than 64 percent of them anticipate being out of the workforce 
for a significant period of time, returning when the youngest child is aged between one and five years. From a human capital perspective, it seems that family care expectations (expectations or plans that are distinct from those held by male S\&T students) are not being built into the career goals and expectations of these female S\&T students. It would, therefore, be erroneous to assume that just because young women and men share similar career expectations they will similarly respond to the shared cultural and institutional environment within S\&T, especially around work and family issues. It is in this regard that human capital theory has limited applicability and limited policy relevance. The following summary and discussion takes up this point.

\section{Summary and Discussion}

In this paper data from the 2003 FYSS have been used to explore the career plans and expectations of S\&T students and to provide insights into the strengths and weaknesses of human capital theory as an explanatory model. The key goal has been to shed further light on the ongoing problem of attraction and retention of women in these fields. Using a series of descriptive statistics and regression analysis this paper has shown some interesting similarities and differences in the career expectations of female S\&T students and male S\&T students, as well as female students in other courses. In addition, there are implications for the widespread application of human capital models of labour market behaviour.

While female and male S\&T students ranked good career opportunities, future earnings potential, and exciting work amongst top job characteristics, on average male S\&T students attached less importance to work and family job features than their female S\&T counterparts. There were also marked differences between male and female S\&T students in terms of their imagined working arrangements when parents, although these differences were complementary to the extent that they aligned with a model in which the male partner adopted the role of full-time breadwinner. More than 50 percent of the male S\&T students imagined a partner relationship where they worked full-time and their female partner worked parttime. Amongst S\&T female students, just over 40 percent imagined themselves in a relationship where they would work part-time while their partner worked full-time. Only 26 percent of S\&T female students imagined they would remain in full-time work as parents in a couple relationship, although this was a higher proportion than among other female students.

From a practitioner perspective it is likely that the attitudes held by S\&T male students, together with the reduced emphasis given to work and family issues as desirable job features, will further reinforce the masculine cultures in S\&T occupations and contribute to the ongoing failure of the industry to respond to 
women's job needs. Female S\&T students will enter the industry pursuing similar goals as their male counterparts (earnings growth, responsibility, promotion, interesting and challenging work) and will struggle to remain attached if the jobs are unable to simultaneously deliver on these requirements and the flexibility requirements that would enable family care. Failure to meet their needs will not only contribute to ongoing costly retention problems and resultant skill shortages, it will also further exacerbate the current fertility crisis in Australia with women in this industry modifying their fertility plans. ${ }^{7}$

From a policy perspective the paper also calls for a more pluralist framework and engagement with feminist research. In the absence of this engagement, policy will remain ill-informed and the pressing challenges associated with women's employment patterns will remain unresolved.

\section{Notes}

1. In human capital theory, for example, individuals are assumed to trade off higher earnings for reduced penalties associated with career breaks and time out of the workforce. This is thought to explain why certain feminised occupations, such as nursing, have flatter wage profiles when compared to other professional jobs.

2. The survey (complete with a copy of the questionnaire) is more fully described in Nowak et al (2003).

3. The over-representation of female students (who accounted for 67 percent of responses) reflects a deliberate over-sampling of nursing students for other research purposes, but it is also common to achieve a higher response rate from women in surveys of this nature (see for example Blau and Ferber 1991).

4. Within the sample the distribution of women across Information Technology/ Information Systems, Engineering, and Chemistry and Physics was equal to 25,19 and 7 respectively (total 51 ).

5. Specifically the question asked: 'What are you looking for in an occupation? Please indicate the importance, if any, you attach to each of the following job characteristics'.

6. Female S\&T students may well find themselves in unsupportive organisational environments, and not just in respect of work and family issues. As Roberts and Ayre (2002: 1) observe about engineering organisations: ' [d]iscrimination, harassment and paternalism are rife'.

7. Examination of unpublished census data shows that around 83 percent of female professional employees in the IT industry aged 30 to 34 years work full-time - a significantly higher rate than in professions such as nursing and teaching. The data also show that a significantly higher proportion of women in IT jobs have no children when compared to their male colleagues 
in IT jobs and to women in other jobs. It may be that women who select the IT industry hold different fertility plans from their counterparts entering other industries. However, an alternative explanation may be that a lack of hours flexibility and quality part-time work has impacted on the fertility plans of women in this industry as career and fertility trade-offs have been made.

\section{Acknowledgements}

Research for this paper has been supported in part by Australian Research Council Discovery Project (DP0209261). I gratefully acknowledge the helpful comments from two anonymous Labour $\&$ Industry referees as well as generous comments and assistance from Gillian Whitehouse and Therese Jefferson.

\section{References}

Becker, G (1975) Human Capital: A Theoretical and Entpirical Analysis with Special Reference to Education, 2nd edn, National Bureau of Economic Research, New York.

Bentley, R (2003) 'Vanishing IT Women', Computer Weekly, 23 February 2003, p. 33.

Blau, F D and Ferber, M A (1991) ‘Career plans and expectations of young women and men: the earnings gap and labour force participation' Joumal of Human Resources 26 (4), pp. 581-607.

Cooper, J and Weaver, KD (2003) Gender and Computers: Understanding the Digital Divide, Lawrence Erlbaum Associates, Mahwah, NJ.

McDonald, P (2000) 'Gender Equity, Social Institutions and the Future of Fertility' Journal of Population Research, 17, pp. 1-16.

Nowak, M, Preston, A, Dockery, M, McCabe R, and Naude, M (2002) Study of Occupational Choice: 2003 Survey of First Year University Students in Western Australin, Computer File, Women's Economic Policy Analysis Unit, Curtin University of Technology.

Polachek, S (1981) 'Occupational self-selection: a human capital approach to sex differences in occupational structure' Review of Economics and Statistics, 63, pp. 60-9.

Poole M E and Langan-Fox J (1997) Australian Women and Careers: Psychological and Contextual Influences over the Life Course, Cambridge University Press, Cambridge.

Preston, A and Burgess, J (2003) 'Women's Work in Australia: Trends, Issues and Prospects' Australim Joumal of Labour Economics 6 (4), pp. 497-518.

Reskin, B and P Roos (1990) Job Queues, Gender Quewes: Explaining Women's Inroads into Male Occupations, Temple University Press, Philadelphia. 
Roberts, P and Ayre, M (2002) Counting the Losses ... The Careers Review of Engineering Women: An investigation of women's retention in the Australian Engineering Workforce, Engineers Australia, Canberra.

Wajcman, J (1991) Feminism Confronts Technology, The Pennsylvania State University Press, University Park, Pennsylvania.

Webster, J (1996) Shaping Women's Work: Gender, Employment and Information Technology, Longman, London.

Weinberger, C J (2004) 'Just Ask! Why surveyed women did not pursue IT courses or careers' IEEE Technology and Society Mngazine, Spring, pp. 28-35.

Whitley, B (1997) 'Gender differences in computer-related attitudes and behavior: a meta-analysis' Contputers in Human Behavior, 13 (1), pp. 1-22.

Wyer, M, Barbercheck, M, Giesman, D, Ozturk H O, Wayne, M (eds) (2001) Women, Science and Technology: A Reader in Feminist Science Studies, Routledge, New York.

ALISON PRESTON - Women in Social E Economic Research (WiSER) Unit, Curtin University of Technology. 